\title{
Lack of efficacy of phenytoin in the syndrome of inappropriate anti-diuretic hormone secretion of neurological origin
}

\author{
Guy Decaux ${ }^{1}$, Serge Przedborski² and Alain Soupart ${ }^{1}$
}

Services of ${ }^{1}$ Internal Medicine and ${ }^{2}$ Neurology, Hopital Universitaire Erasme, and the Institute of Interdisciplinary Research, School of Medicine, Free University of Brussels, Belgium

\begin{abstract}
Summary: Phenytoin has been proposed in the management of patients with the syndrome of inappropriate secretion of anti-diuretic hormone (SIADH) of neurological origin who fail to respond to water restriction.

We have conducted a prospective study in order to evaluate the role of phenytoin in the management of seven consecutive patients with SIADH of neurological origin which could not be controlled by limited water intake. Only one patient was successfully treated with chronic phenytoin regimen. This patient, like one previously reported, had suffered a basal skull fracture. It seems likely that in the majority of cases of SIADH of neurological origin phenytoin is ineffective on a long-term basis.
\end{abstract}

\section{Introduction}

Various treatments have been proposed ${ }^{1-4}$ in the management of patients with hyponatraemia related to the syndrome of inappropriate secretion of antidiuretic hormone (SIADH), when water restriction appears ineffective. Demeclocycline, ${ }^{1}$ urea $^{3}$ and frusemide ${ }^{4}$ have been used successfully.

For SIADH of neurological origin, a trial with phenytoin has been suggested. ${ }^{2,5}$ However, although phenytoin acutely decreases ADH secretion, ${ }^{6}$ effective chronic management has been reported in only one case. $^{2}$ The drug can however reverse the carbamazepine-induced water intoxication. ${ }^{7.8} \mathrm{We}$ have conducted a prospective study in order to evaluate the role of phenytoin in the management of seven consecutive patients with SIADH of neurological origin which could not be controlled by limited water intake.

\section{Patients and results}

Over a 3-year period we studied seven cases of chronic SIADH of neurological origin which could not be controlled by simple water restriction $(\mathrm{Na}<$ $128 \mathrm{mmol} / \mathrm{l}$ after 5 days). All the patients fulfilled the criteria of SIADH, ${ }^{9}$ namely (1) hyponatraemia (nor-

Correspondence: G. Decaux, M.D., Ph.D., Service de Médecine Interne, route de Lennik, 808, 1070 Brussels, Belgium

Accepted: 17 February 1989

This work was supported by a grant from the Ministère de la Politique Scientifique (Actions concertées). mal range $135-145 \mathrm{mmol} / \mathrm{l})$ and hypo-osmolality $\vec{c}$ (normal range $270-300 \mathrm{mOsm} / \mathrm{kg} \mathrm{H}_{2} \mathrm{O}$ ) in the presence of inappropriately high urine osmolality; (2) $\vec{\bullet}$ urinary sodium greater than $30 \mathrm{mmol} / \mathrm{l}$ and $(3)$ absence of volume depletion, oedema, cardiac hepatic disease. All patients had normal renal, adren⿳亠口冋. and thyroid function, and normal blood glucose levels़t None of the patients took a medication known to interfere with water metabolism.

Details of the patients are shown in Table 1 . They $\stackrel{\mathbb{Q}}{\stackrel{2}{\circ}}$ received orally $900 \mathrm{mg}$ of phenytoin on the first day $\overrightarrow{\vec{O}}$ and subsequently $300 \mathrm{mg} /$ day, and continued water 3 restriction $(<1$ litre/day). Blood concentration of $\vec{F}$ phenytoin was measured after one week.

After one week, with phenytoin blood levels within the therapeutic range for seizure control $(10-20 \mu \mathrm{g} / \underline{\underline{3}}$. $\mathrm{ml})$, treatment was stopped when serum sodium concentration failed to reach $135 \mathrm{mmol} / \mathrm{l}$. In the two patients with tuberculosis meningitis, phenytoin was $\delta$ maintained for a few months in order to control $₹$ seizure. Despite this prolonged administration, no 읙 effect of phenytoin on hyponatraemia could be $\rightarrow$ observed.

Only one patient clearly responded to the phenytoin trial (case no. 3). This patient was a 30 year old man with a basal skull fracture in 1979 . He was admitted in $N$ November 1987 with a serum sodium concentration of $\underset{\omega}{N}$ $116 \mathrm{mmol} / \mathrm{l}$. A computed tomographic scan of the brain was normal. After 5 days of severe water 0 restriction $(<500 \mathrm{ml} /$ day $)$, serum sodium concentration increased to $126 \mathrm{mmol} / \mathrm{l}$.

Subsequently, a standard oral water loading test (20 ml/kg body weight) was performed, showing that

C) The Fellowship of Postgraduate Medicine, 1989 
Table I Clinical and laboratory observations in seven patients with SIADH treated with phenytoin

\begin{tabular}{|c|c|c|c|c|c|c|c|c|}
\hline \multicolumn{2}{|c|}{$\begin{array}{l}\text { Sex-age } \\
\text { (years) }\end{array}$} & \multirow{2}{*}{$\begin{array}{l}\text { Diagnosis } \\
\text { Brain } \\
\text { haemorrhage }\end{array}$} & \multirow{2}{*}{$\begin{array}{c}\begin{array}{c}\text { Serum } \mathrm{Na}^{+} \\
\text {before water } \\
\text { restriction } \\
\text { (mmol/l) }\end{array} \\
119\end{array}$} & \multirow{2}{*}{$\begin{array}{c}\begin{array}{c}\text { Serum } \mathrm{Na}^{+} \\
\text {after water } \\
\text { restriction } \\
\text { (mmol/l) }\end{array} \\
124\end{array}$} & \multirow{2}{*}{$\begin{array}{c}\begin{array}{c}\text { Before treatment } \\
\text { Blood/urine } \\
\text { osmolality } \\
(\mathrm{mOsm} / \mathrm{kg} \mathrm{H} \mathrm{O})\end{array} \\
259 / 402\end{array}$} & \multirow{2}{*}{$\begin{array}{c}\begin{array}{c}\text { Serum } \mathrm{Na}^{+} \\
\text {during } \\
\text { phenytoin } \\
(\text { mmol/l) }\end{array} \\
122\end{array}$} & \multirow{2}{*}{$\begin{array}{l}\begin{array}{l}\text { During treatment } \\
\text { blood osmolality } \\
\left(\mathrm{mOsm} / \mathrm{kg} \mathrm{H} \mathrm{H}_{2} \mathrm{O}\right)\end{array} \\
252\end{array}$} & \multirow{2}{*}{$\begin{array}{c}\begin{array}{c}\text { Blood } \\
\text { phenytoin } \\
(\mu \mathrm{g} / \mathrm{ml})\end{array} \\
15\end{array}$} \\
\hline 1 & $F-60$ & & & & & & & \\
\hline 2 & F-70 & $\begin{array}{l}\text { Cerebral } \\
\text { thrombosis }\end{array}$ & 123 & 123 & $254 / 618$ & 121 & 248 & 13 \\
\hline 3 & M-30 & $\begin{array}{l}\text { Basal } \\
\text { skull } \\
\text { fracture }\end{array}$ & 116 & 120 & $245 / 500$ & 136 & 285 & 19 \\
\hline 4 & M-50 & $\begin{array}{l}\text { Tuberculous } \\
\text { meningitis }\end{array}$ & 115 & 125 & $256 / 700$ & 126 & 258 & 14 \\
\hline 5 & M-49 & $\begin{array}{l}\text { Tuberculous } \\
\text { meningitis }\end{array}$ & 119 & 124 & $255 / 500$ & 125 & 260 & 16 \\
\hline 6 & F-70 & Cortical atrophy & 120 & 125 & $260 / 540$ & 123 & 255 & 17 \\
\hline 7 & F-75 & Cortical atrophy & 122 & 127 & $258 / 400$ & 123 & 255 & 13 \\
\hline
\end{tabular}

the patient could excrete only $30 \%$ of the water load within a 5-hour collection period (normal response: $>80 \%$ of the water load excreted in 4 hours). The minimal urine osmolality achieved during this period was $500 \mathrm{mOsm} / \mathrm{kg} \mathrm{H}_{2} \mathrm{O}$ (normal $<100 \mathrm{mOsm} / \mathrm{kg}$ $\mathrm{H}_{2} \mathrm{O}$ ). A second water loading test was performed after phenytoin administration (blood level $16 \mu \mathrm{g} / \mathrm{ml}$ ) with a serum sodium concentration of $136 \mathrm{mmol} / \mathrm{l}$. The patient this time excreted $50 \%$ of the water load in 5 hours with a minimal urine osmolality of $189 \mathrm{mOsm} / \mathrm{kg} \mathrm{H}_{2} \mathrm{O}$ at the fifth hour. During the follow-up, the serum sodium level remained within the normal range, with 24-hour urine output being as high as $2800 \mathrm{ml}$. At each attempt to decrease phenytoin dosage $(200 \mathrm{mg} /$ day, blood level $<10 \mu \mathrm{g} / \mathrm{ml})$, serum sodium decreased after a few days $(<130 \mathrm{mmol} / \mathrm{l})$ and returned to normal range when a full dose was readministered. The patient is still successfully treated on a long-term basis with more than 10 months of normal serum sodium levels despite free water access.

\section{Discussion}

It has been demonstrated that phenytoin, when acutely administered, (intravenously or intramuscularly) can suppress ADH release by the posthypophysis. ${ }^{6}$ Fichman et al. describe the capacity of phenytoin given intravenously to increase the free water clearance and to lower the minimal urine osmolality in patients with SIADH of neurological origin. ${ }^{6}$ However, they conclude that phenytoin is probably not effective for long-term management of this syndrome, as the effect of ADH suppression occurs mainly during the rising phase of blood phenytoin concentration. It has to be noted that one previously published case with a SIADH related to a basal skull fracture, was also successfully treated chronically with phenytoin. ${ }^{2}$

The results of our study show that phenytoin was effective in chronically inhibiting the secretion of $\mathrm{ADH}$ in only one of the seven patients studied, although even here complete inhibition could not be achieved as reflected by a subnormal excretion of oral water load. The others were treated either by urea or frusemide. ${ }^{3,4}$

These data suggest that phenytoin is ineffective in the chronic control of SIADH of neurological origin in a majority of cases. We can but speculate why phenytoin had an action only in the patient with a SIADH following basal skull fracture. It has been reported that SIADH with this condition results from a constant, non-suppressible release or 'leak' of vasopressin under hypotonic conditions despite otherwise normal osmoreceptor function (the so called SIADH of type $\mathrm{C}^{10}$ ). Such non-suppressible central secretion of vasopressin may be due to hyperfunction of stimulatory neurones, hypofunction of proposed inhibitory neurones or injury to the neurohypophysis itself. ${ }^{11}$ As phenytoin is known to inhibit the calcium influx, ${ }^{12}$ which plays a key role in the neurosecretion mechanism of $\mathrm{ADH},{ }^{13}$ it is possible that in this type of SIADH phenytoin could significantly inhibit ADH release. 


\section{References}

1. Forrest, J.N., Cox, M., Hong, C., Morrison, G., Bia, M. \& Singer, I. Superiority of demeclocycline over lithium in the treatment of chronic syndrome of inappropriate secretion of antidiuretic hormone. N Engl J Med 1978, 298: 173-177.

2. Tanay, A., Yust, E., Perescenschi, G., Abramov, A.L. \& Aviram, A. Long-term treatment of the syndrome of inappropriate antidiuretic hormone secretion with phenytoin. Ann Intern Med 1979, 90: 50-52.

3. Decaux, G. \& Genette, F.R. Urea for long-term treatment of the syndrome of inappropriate secretion of antidiuretic hormone. Br Med J 1981, 283: 1081-1083.

4. Decaux, G., Waterlot, Y., Genette, F.R., Hallemans, R. \& Demanet, J.C. Inappropriate secretion of antidiuretic hormone treated with frusemide. $\mathrm{Br} \mathrm{Med} J$ 1982, 285: 89-90.

5. Schrier, R.W. Treatment of hyponatremia. N Engl J Med 1985, 312: $1121-1123$.

6. Fichman, M.P., Kleeman, C.R. \& Bethune, J.E. Inhibition of antidiuretic hormone secretion by Diphenylhydantoin. Arch Neurol 1970, 22: 45-53.

7. Sordillo, P., Sagransky, D.M., Mercado, R. \& Michelis, M.F. Carbamazepine-induced syndrome of inappropriate antidiuretic hormone secretion: reversal by concomittant phenytoin therapy. Arch Intern Med 1978, 138: 299-302.
8. Perruca, E. \& Richens, A. Reversal by phenytoin $\frac{{ }_{0} f}{}$ carbamazepine-induced water intoxication: a pharmacokinetic interaction. J Neurol Neurosurg Psychiaftry 1980, 43: 540-545.

$\overrightarrow{\overline{\vec{x}}}$

9. Bartter, F.C. The syndrome of inappropriate secretion antidiuretic hormone (SIADH). DM, November 1993, pp. 1-47.

10. Robertson, G.L., Shelton, R.L. \& Athar, S. Whe osmoregulation of vasopressin. Kidney Int 1976, 25-37.

11. Zerbe, R., Stropes, L. \& Robertson, G.L. Vasopressin function in the syndrome of inappropriate antidiuressis. Ann Rev Med 1980, 31: 315-327.

12. Goddard, G.A. \& Robinson, J.D. Uptake and release $\overrightarrow{\emptyset f}$ calcium by rat brain synaptosomes. Brain Res 1976, 190: 331-350.

13. Ishikawa, S. \& Schrier, R.W. Role of calcium in osm s]ic and nonosmotic release of vasopressin from rat orgin culture. Am J Physiol 1983, 244: R703-R709. 